\title{
Total Syntheses and Configuration Assignments of JBIR-06 and Related Depsipeptides
}

Chie Hamada, Yoshinosuke Usuki, Daiki Takeuchi, Hikaru Ogawa, Ryota Abe, Tetsuya Satoh

\begin{tabular}{|c|c|}
\hline Citation & Organic Letters, 21 (4); 965-968 \\
\hline Issue Date & 2019-01-30 \\
\hline Type & Journal article \\
\hline Text version & author \\
\hline Rights & $\begin{array}{l}\text { This document is the Accepted Manuscript version of a Published Work that } \\
\text { appeared in final form in Organic Letters, copyright } @ \text { American Chemical Society } \\
\text { after peer review and technical editing by the publisher. To access the final edited } \\
\text { and published work see https://doi.org/10.1021/acs.orglett.8b03944 }\end{array}$ \\
\hline $\begin{array}{l}\text { Supporting } \\
\text { Information }\end{array}$ & $\begin{array}{l}\text { The Supporting Information is available free of charge on the ACS Publications } \\
\text { website at https://doi.org/10.1021/acs.orglett.8b03944. }\end{array}$ \\
\hline DOI & 10.1021/acs.orglett.8b03944 \\
\hline
\end{tabular}

Self-Archiving by Author(s)

Placed on: Osaka City University

HAMADA C, USUKI Y, TAKEUCHI D, OGAWA H, ABE R, \& SATOH T. (2019). Total Syntheses and Configuration Assignments of JBIR-06 and Related Depsipeptides. Organic Letters. 21, 965-968.

doi:10.1021/acs.orglett.8b03944 


\title{
Total Syntheses and Configuration Assignments of JBIR-06 and Re- lated Depsipeptides
}

\author{
Chie Hamada, Yoshinosuke Usuki, ${ }^{*}$ Daiki Takeuchi, Hikaru Ogawa, Ryota Abe, and Tetsuya Satoh \\ Department of Chemistry, Graduate School of Science, Osaka City University, 3-3-138 Sugimoto, Sumiyoshi, Osaka 558- \\ 8585, Japan
}

Supporting Information

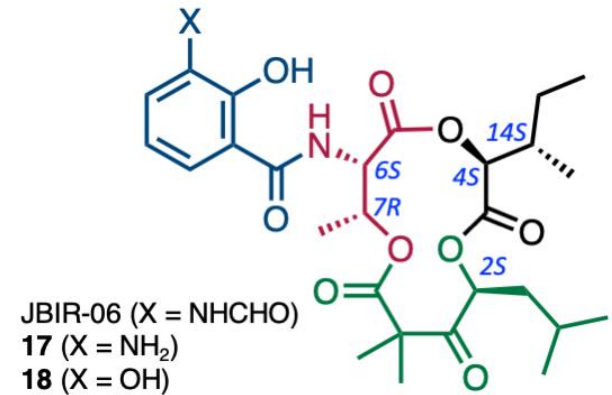

\begin{abstract}
The first total syntheses of JBIR-06 and two analogous depsipeptides, 12-membered antimycin-class antibiotics, have been accomplished via Shiina macrolactonization. Comparison of the spectroscopic data of the synthesized compounds with those reported for natural products verified that the absolute configutation of the natural products was $(2 S, 4 S, 6 S, 7 R, 14 S)$.
\end{abstract}

Antimycin-class antibiotics contain a macrocyclic ring (9-, 12-, 15-, or 18-membered) with a 3-(formylamino)-2-hydroxybenzoic acid attached to an L-threonine moiety via an amide bond. ${ }^{1}$ The ring size and ring substitution result in much structural diversity. Antimycin-type antibiotics have attracted significant interest because of their diverse biological activities, including anticancer, antifungal, and immunosuppressant properties. ${ }^{2}$ The biosynthetic pathway for a common cyclic skeleton toward antimycin family production with high structural diversity has been investigated, and the construction of analogues of this scaffold from natural sources has been attempted. ${ }^{3}$

JBIR-06 (1) was isolated from Streptomyces sp. ML-55 by Shin-ya and co-workers. ${ }^{4}$ Compound 1 showed inhibitory activity against glucose-regulated protein 78 (GRP78) expression in 2-deoxy-D-glucose (2DG)-treated HT1080 cells ( IC $_{50}: 262$ $\mathrm{nM})$. High levels of GRP78 have been implicated in cancer growth and chemoresistance because of its upregulation in tumor cells. ${ }^{5}$ GRP-78 downregulators, which accelerate apoptosis of cancerous cells, would be promising agents for targeted cancer therapies. The inhibitory activity of JBIR-06 against GRP78 expression was 130-fold lesser than that of prunustatin A (2), ${ }^{6}$ a 15-membered antimycin antibiotic, suggesting that the ring size is crucial for the inhibition of increased GRP78 expression induced by 2-DG treatment (Figure 1).

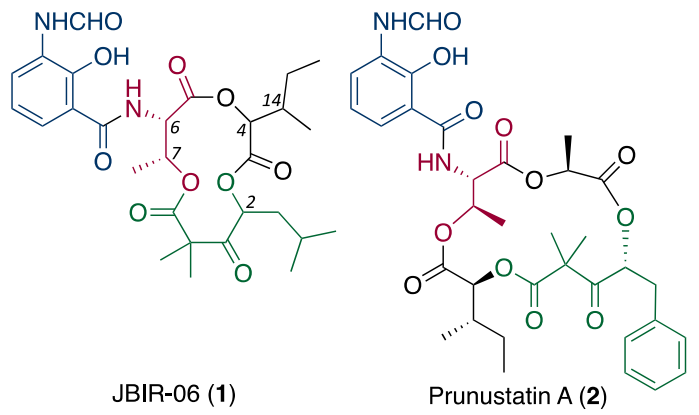

Figure 1. Structures of JBIR-06 (1) and Prunustatin A (2).

2D NMR analyses revealed that $\mathbf{1}$ is a new member of the antimycin family, and that it features a 12 -membered trilactone. The absolute configuration of the threonine moiety of $\mathbf{1}$ was elucidated to be L by Marfey's method; however, the other three stereogenic centers were not determined. During our studies on the total syntheses of antimycin-type antibiotics, ${ }^{7}$ we focused on the total synthesis and stereochemical elucidation of $\mathbf{1}$. Recently, Awakawa and Abe et al. have reported the production of JBIR-06 and related ring-expansion compounds with reprogramming of the antimycin NRPS (nonribosomal peptide synthase)/PKS (polyketide synthase) assembly line. ${ }^{8}$ They carried out the acid-catalyzed degradation of their products and GC-MS analyses with a chiral column to confirm that the stereochemistry of each building block in JBIR-06 was L. Therefore, we 
focused on the synthetic confirmation of the reported stereochemistry of $\mathbf{1}$. Herein, we report our endeavors for the preparation of 12-membered trilactone derivatives.

We presumed that JBIR-06 has the $(2 S, 4 S, 6 S, 7 R, 14 S)$ configuration. We embarked on a synthetic route to the desired compound 3 by cyclization via Shiina macrolactonization ${ }^{9}$ for the construction of the 12-membered trilactone core, followed by amidation of $\mathbf{4}$ with $\mathbf{5}$ and deprotection (Scheme 1).
Conceptually, bis-benzyl protected $\mathbf{8}$ would be prepared by the intermolecular transesterification ${ }^{10}$ of 9 and $N$-Boc-L-threonine benzyl ester 10. Mechanistic studies suggest that the transesterification of $\beta$-keto esters proceeds via the corresponding acyl ketene intermediate; ${ }^{10 \mathrm{c}, \mathrm{d}}$ that is the other ester moieties in $\mathbf{9}$ and 10 would not be effective during the conversion into 8. Compound 9 would be obtained by the condensation of $11,{ }^{11}$ which is derived from L-isoleucine, with $\beta$-ketoester 12.

\section{Scheme 1. Retrosynthesis of the Target Molecule (3)}

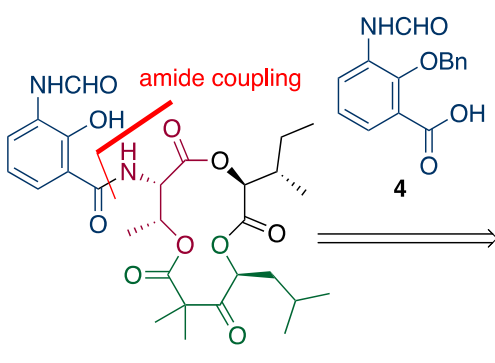

3

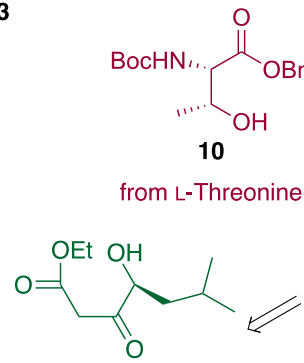

12

from L-Leucine

Scheme 2. Synthesis of Fragment 9
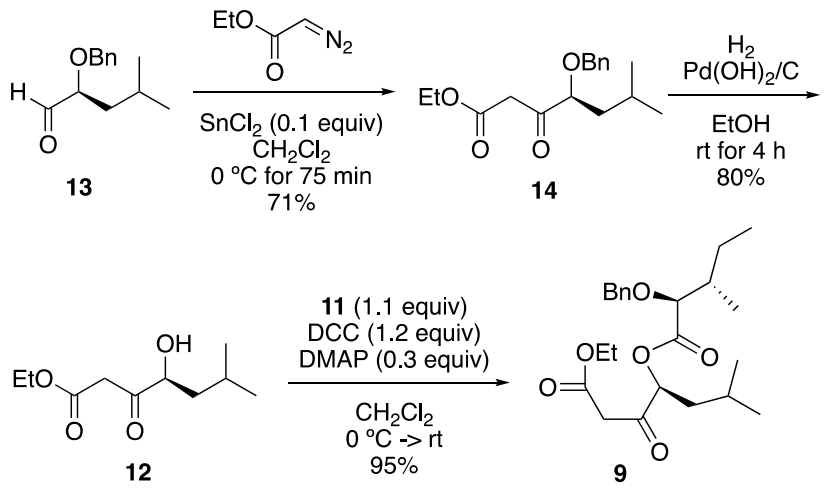

The reaction of aldehyde $\mathbf{1 3}$, derived from L-leucine, with ethyl diazoacetate in the presence of $\mathrm{SnCl}_{2}$ (0.1 equiv) provided the corresponding $\beta$-keto ester 14 in $71 \%$ yield as a tautomeric and rotameric mixture. ${ }^{12}$ Hydrogenolysis of $\mathbf{1 4}$ in the presence of $\mathrm{Pd}(\mathrm{OH})_{2}$ in EtOH resulted in removal of the benzyl ether protecting group to afford compound $\mathbf{1 2}$ in $80 \%$ yield. Fragment 9 was prepared by coupling 11 with $\mathbf{1 2}$ in the presence of DCC and DMAP in $95 \%$ yield (Scheme 2 ).

Slow addition of $\mathbf{1 0}$ in toluene to the mixture of $\mathbf{9}$ and anhydrous $\mathrm{CuSO}_{4}\left(0.7\right.$ equiv) in toluene over $3 \mathrm{~h}$ at $100^{\circ} \mathrm{C}$ and subsequent reflux for overnight successfully furnished intermolecular transesterification to provide the desired $\mathbf{8}$ in $59 \%$ yield. Double methylation at the $\mathrm{C} 9$ position of $\mathbf{8}$ was achieved using
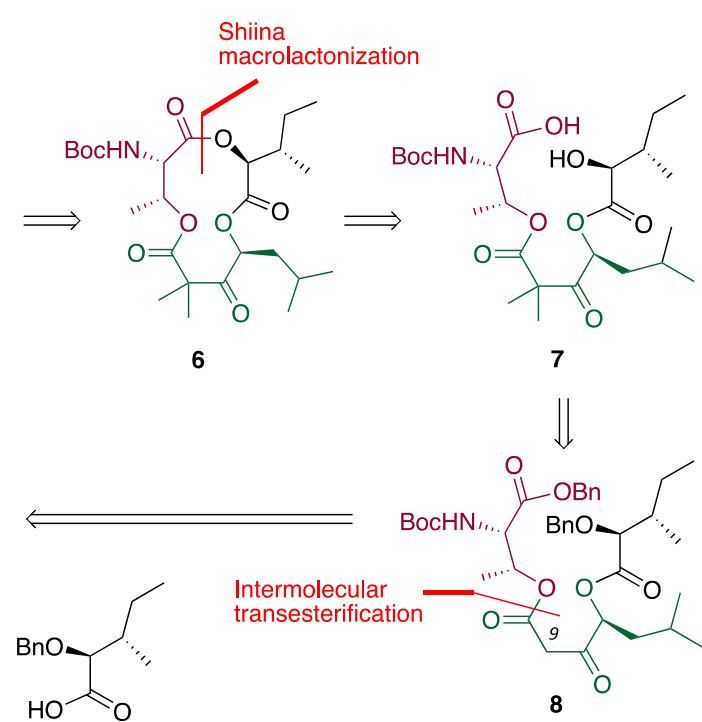

11

from L-Isoleucine

iodomethane (2.9 equiv) and $\mathrm{Na}_{2} \mathrm{CO}_{3}$ (9.2 equiv) in DMSO at rt for $4 \mathrm{~h}$ to provide the corresponding 15 in $83 \%$ yield. Reductive deprotection of the benzyl groups in the presence of $\mathrm{Pd}(\mathrm{OH})_{2}$ in EtOAc under $\mathrm{H}_{2}$ atmosphere afforded the desired seco acid 7 in quantitative yield (Scheme 3).

We next adapted Shiina macrolactonization with MNBA (2methyl-6-nitrobenzoic anhydride)/DMAP for the ring closure of 7,, 13 and examined several sets of conditions. In each case, dimer formation was not observed by ESI/MS. Finally, we found that under high-dilution condition $(1.6 \mathrm{mM})$, slow addition of 7 into MNBA /DMAP over $7 \mathrm{~h}$ at rt and subsequent stirring for $20 \mathrm{~h}$ successfully furnished the key 12-membered trilactone 6 in 74\% yield. The gem-dimethyl effect facilitated this macrolactonization: seco acid without a gem-dimethyl group would not cyclize under these conditions. ${ }^{14}$

At endgame of the total synthesis of $\mathbf{3}$, the Boc group of $\mathbf{6}$ was removed with TFA in dichloromethane to afford amine 5. Subsequent condensation of 5 with benzyl ether $4^{15}$ using EDCI, $\mathrm{HOBt}$, and NMM in DMF provided the corresponding amide 16 in $85 \%$ yield from 6 . Finally, reductive removal of the benzyl ether protecting group was accomplished in the presence of $\mathrm{Pd}(\mathrm{OH})_{2}$ in EtOAc under $\mathrm{H}_{2}$ atomosphere and the desired 3 was obtained in $91 \%$ yield (Scheme 4 ).

The spectral data of synthetic 3 were identical to those reported for the natural product (Table S1). The optical rotation of synthetic $3\left([\alpha]_{D}-27.5\right.$, c $\left.0.03, \mathrm{MeOH}\right)$ was in good agreement with that of the natural sample $\left([\alpha]_{\mathrm{D}}-30.0, \mathrm{c} 0.04, \mathrm{MeOH}\right)$. Comparison of the spectroscopic data between the synthetic 3 
and natural $\mathbf{1}$ verified the absolute configuration of $\mathbf{1}$ is $(2 S, 4 S$, $6 S, 7 R, 14 S)$.

Scheme 3. Intermolecular Transesterification and Double Deprotection/Macrocyclization
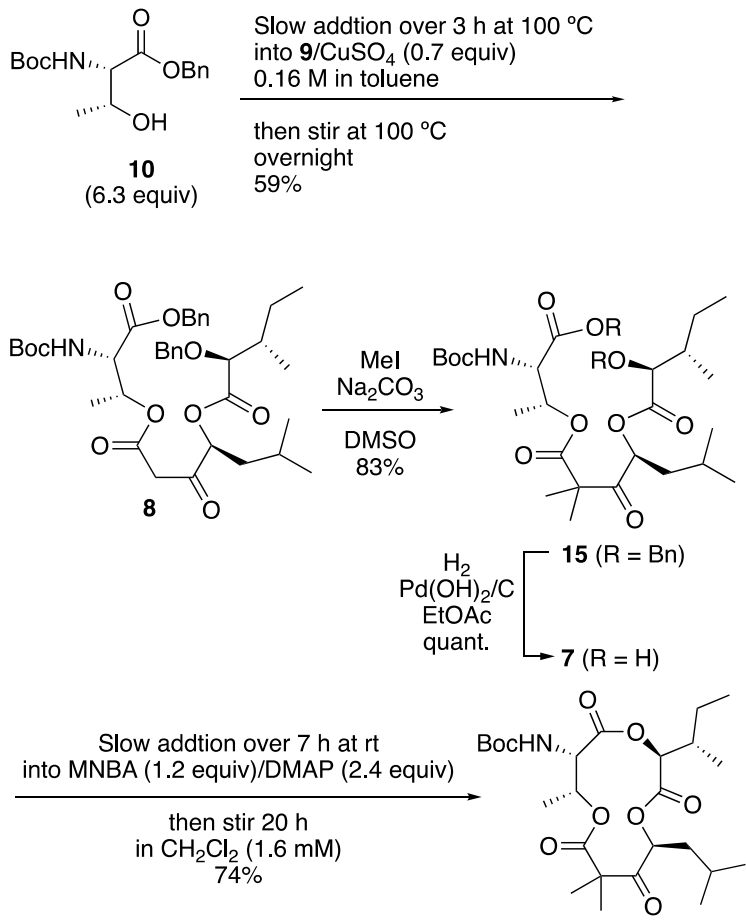

Scheme 4. Completion of the Synthesis of 3

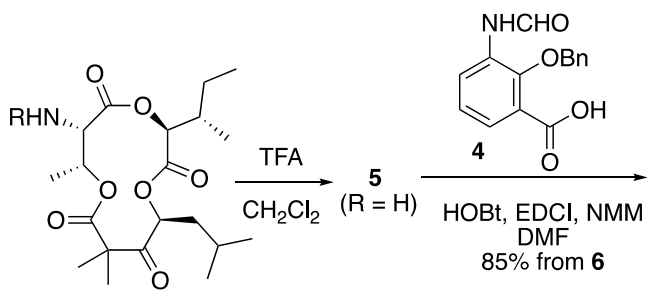

$6(\mathrm{R}=\mathrm{Boc})$

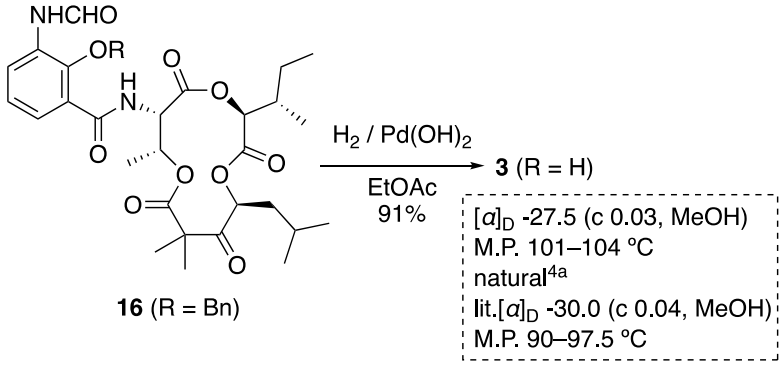

Magarvey reported two analogous 12-membered depsipeptides 17 and 18 from Streptomyces sp. ML-55, ${ }^{4 b}$ whose NMR data were similar to those of JBIR-06 (1), except for the signals pertaining to the benzoic acid moiety. An advanced Marfey's method suggested that the threonine residue found in $\mathbf{1 7}$ and $\mathbf{1 8}$ had the L-configuration. Comprehensive analysis of 2D NMR data revealed the planar structure of $\mathbf{1 7}$ and 18, as shown in Figure 2 , which would be confirmed by total synthesis.

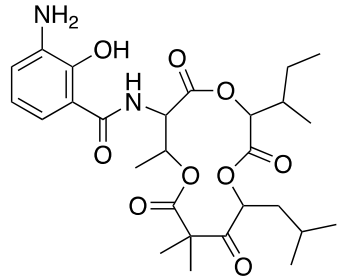

17

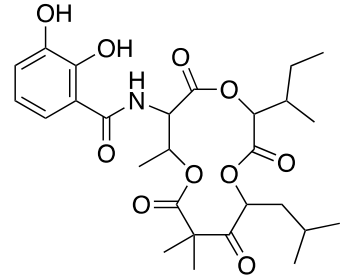

18
Figure 2. Structures of Two Analogous Depsipeptides 17 and 18.

Removal of the Boc group of $\mathbf{6}$ with TFA in dichloromethane, followed by condensation of $\mathbf{5}$ with the commercially available 3-nitrosalicylic acid 19 or dibenzyl ether $\mathbf{2 0}^{16}$ using EDCI, $\mathrm{HOBt}$, and NMM in DMF provided the corresponding amide $\mathbf{2 1}$ or $\mathbf{2 2}$ in $51 \%$ or $55 \%$ yield from $\mathbf{6}$. Reduction of $\mathbf{2 1}$ in the presence of $\mathrm{Pd}(\mathrm{OH})_{2}$ in EtOAc under $\mathrm{H}_{2}$ atmosphere afforded the desired $\mathbf{2 3}$ in $89 \%$ yield. Reductive removal of the benzyl ether protecting groups from 22 in the presence of $\mathrm{Pd}(\mathrm{OH})_{2}$ in EtOAc under $\mathrm{H}_{2}$ atmosphere provided $\mathbf{2 4}$ in $73 \%$ yield (Scheme $5)$.

Scheme 5. Endgame to the Synthesis of 23 and 24
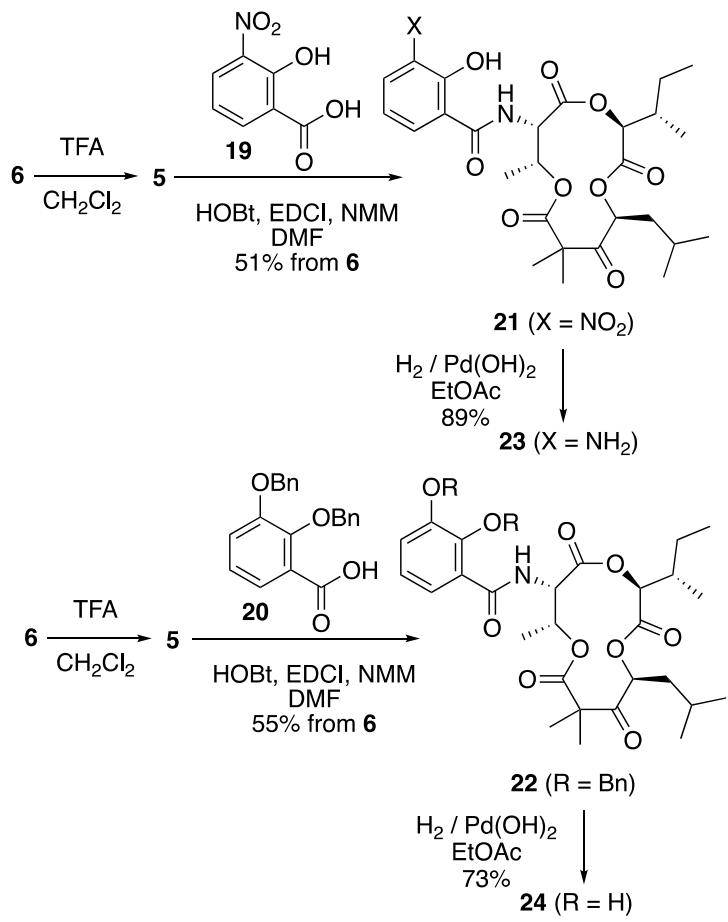

Unfortunately, the optical rotation values of the natural products $\mathbf{1 7}$ and $\mathbf{1 8}$ are not available. The other spectral data for the synthetic $\mathbf{2 3}$ and $\mathbf{2 4}$ were in good agreement with those reported for the natural 17 and 18 (Table S2 and S3): The absolute configuration of natural 17 and $\mathbf{1 8}$ was assigned as $(2 S, 4 S, 6 S, 7 R$, $14 S$ ) based on the total synthesis.

In conclusion, the first total syntheses of JBIR-06 and related two depsipeptides were accomplished by Shiina macrocyclization with MNBA/DMAP. Synthetic confirmation of the absolute configuration of $\mathbf{1}, \mathbf{1 7}$, and $\mathbf{1 8}$ was thus achieved. Further studies aimed at the biological evaluation of these 12-membered trilactone antibiotics are in progress, and the results will be reported in due course. 


\section{ASSOCIATED CONTENT}

\section{Supporting Information}

The Supporting Information is available free of charge on the ACS Publication website.

Comparisons of NMR Data of Natural and Synthetic compounds (Table S1, S2 and S3), Synthetic procedures and characterization data for compounds $3, \mathbf{5}, \mathbf{6}, \mathbf{8}, \mathbf{9}, \mathbf{1 2}-\mathbf{1 6}$, and 21-24 including ${ }^{1} \mathrm{H}$ and ${ }^{13} \mathrm{C}$ NMR spectra (PDF).

\section{AUTHOR INFORMATION}

\section{Corresponding Author}

*E-mail: usuki@sci.osaka-cu.ac.jp

\section{Author Contributions}

All authors have approved the final version of the manuscript.

Notes

The authors declare no competing financial interest.

\section{ACKNOWLEDGMENT}

We are grateful to Dr. Kazuo Shin-ya from the National Institute of Advanced Industrial Science and Technology for the ${ }^{1} \mathrm{H}$ spectra of naturally isolated JBIR-06. We also thank Dr. Matsumi Doe, Analytical Division, Osaka City University, for the 2D NMR measurements. The partial support extended by the Osaka City University (OCU) Strategic Research Grant 2017 for top-priority research (YU), JSPS KAKENHI Grant Number JP18H04627 in Frontier Research on Chemical Communications (YU) and Grant Number JP16H01037 in Precisely Designed Catalysts with Customized Scaffolding (TS) is greatly appreciated.

\section{REFERENCES}

(1) For a recent review, see. Liu, J.; Zhu, X.; Kim, S. J.; Zhang, W. Nat. Prod. Rep. 2016, 33, 1146-1165.

(2) (a) Hanafi, M.; Shibata, K.; Ueki, M.; Taniguchi, M. J. Antibiot. 1996, 49, 1226-1231; (b) Strangman, W. K.; Kwon, H. C.; Broide, D.; Jensen, P. R.; Fenical, W. J. Med. Chem. 2009, 52, 2317-2327. (c) Inai, M.; Nishii, T.; Tanaka, A.; Kaku, H.; Horikawa, M.; Tsunoda, T. Eur. J. Org. Chem. 2011, 2719-2729; (d) Yamakoshi, S.; Kawanishi, E. Tetrahedron Lett. 2014, 55, 1175-1177; (e) Salim, A. A.; Cho, K. J.; Tan, L.; Quezada, M.; Lacey, E.; Hancock, J. F.; Capon, R. J. Org. Lett. 2014, 16, 5036-5039; (f) Yoshida, K.-I.; Ijiri, M.; Iio, H.; Usuki, Y. Tetrahedron 2015, 71, 9626-9629; (g) Lim, C. L.; Nogawa, T.; Okano, A.; Futamura, Y.; Kawatani, M.; Takahashi, S.; Ibrahim, D.; Osada, H. J. Antibiot. 2016, 69, 456-458; (h) Manaviazar, S.; Nockemann, P.; Hale, K. J. Org. Lett. 2016, 18, 2902-2905; (i) Yamakoshi, S.; Okamoto, M.; Sawamoto, H.; Arai, Y.; Kawanishi, E.; Sasaki, M.; Takeda, K. Cur. Org. Synth. 2017, 14, 299-308; (j) Chojnacka, M. W.; Batey, R. A. Org. Lett. 2018, 20, 5671-5675; (k) Usuki, Y.; Ishii, S.; Ijiri, M.; Yoshida, K.-i.; Satoh, T.; Horigome, S.; Yoshida, I.; Mishima, T.; Fujita, K.-i. J. Nat. Prod. 2018, 81, 2590-2594.

(3) (a) Yan, Y.; Zhang, L.; Ito, T.; Qu, X.; Asakawa, Y.; Awakawa, T.; Abe, I.; Liu, W. Org. Lett. 2012, 14, 4142-4145; (b) Sandy, M.; Rui, Z.; Gallagher, J.; Zhang, W. ACS Chem. Biol. 2012, 7, 1956-1961; (c) Yan, Y.; Chen, J.; Zhang, L.; Zheng, Q.; Han, Y.; Zhang, H.; Zhang, D.; Awakawa, T.; Abe, I.; Liu, W. Angew. Chem., Int. Ed. 2013, 52, 12308-12312; (d) Vanner, S. A.; Li, X.; Zvanych, R.; Torchia, J.; Sang, J.; Andrews, D. W.; Magarvey, N. A. Mol. BioSyst. 2013, 9, 2712-2719; (e) Skyrud, W.; Liu, J.; Thankachan, D.; Cabrera, M.; Seipke, R. F.; Zhang, W. ACS Chem. Biol. 2018, 13, 1398-1406; (f) Zhou, Y.; Lin, X.; Williams, S. R.; Liu, L.; Shen, Y.; Wang, S.-P.; Sun, F.; Xu, S.; Deng, H.; Leadlay, P. F.; Lin, H.-W. ACS Chem. Biol. 2018,
13, 2153-2160; (g) Li, Y.; Zhang, W.; Zhang, H.; Tian, W.; Wu, L.; Wang, S.; Zheng, M.; Zhang, J.; Sun, C.; Deng, Z.; Sun, Y.; Qu, X.; Zhou, J. Angew. Chem., Int. Ed. 2018, 57, 5823-5827.

(4) Isolation and structure elucidation of JBIR-06: (a) Ueda, J.-y.; Nagai, A.; Izumikawa, M.; Chijiwa, S.; Takagi, M.; Shin-ya, K. J. Antibiot. 2008, 61, 241-244; Biosynthesis: (b) Li, X.; Zvanych, R.; Torchia, J.; Magarvey, N. A. Bioorg. Med. Chem. Lett. 2013, 23, 41504153.

(5) (a) Luo, B.; Lee, A. S. Oncogene 2013, 32, 805-818; (b) Pyrko, P.; Schonthal, A. H.; Hoffman, F. M.; Chen, T. C.; Lee, A. S. Cancer. Res. 2007, 67, 9809-9816.

(6) Prunustatin A isolation: (a) Umeda, Y.; Chijiwa, S.; Furihata, K.; Furihata, K.; Sakuda, S.; Nagasawa, H.; Watanabe, H.; Shin-ya, K. J. Antibiot. 2005, 58, 206-209; Absolute chemistry: (b) Umeda, Y.; Furihata, K.; Sakuda, S.; Nagasawa, H.; Ishigami, K.; Watanabe, H.; Izumikawa, M.; Takagi, M.; Doi, T.; Nakao, Y.; Shin-ya, K. Org. Lett. 2007, 9, 4239-4242.

(7) Prunustatin A synthesis: (a) Usuki, Y.; Ogawa, H.; Yoshida, K.i.; Inaoka, T.; Iio, H. Asian J. Org. Chem. 2015, 4, 737-740; Neoantimycin synthesis: (b) Ogawa, H.; Iio, H.; Usuki, Y. Chem. Lett. 2015, 44, 1214-1216; JBIR-04 and unantimycin synthesis: (c) Usuki, Y.; Hamada, C.; Satoh, T. Org. Biomol. Chem. 2017, 15, 7346-7351.

(8) Awakawa, T.; Fujioka, T.; Zhang, L.; Hoshino, S.; Hu, Z.; Hashimoto, J.; Kozone, I.; Ikeda, H.; Shin-ya, K.; Liu, W.; Abe, I. Nature Commun. 2018, 9, 3534.

(9) (a) Shiina, I.; Kubota, M.; Oshiumi, H.; Hashizume, M. J. Org Chem. 2004, 69, 1822-1830; (b) Shiina, I. Bull. Chem. Soc. Jpn. 2014, 87, 196-233.

(10) (a) For a general review on transesterification, see: Otera, J. Chem. Rev. 1993, 93, 1449-1470; (b) For a recent example of transesterification in a total synthesis, see: Williams, D. R.; Myers, B. J.; Mi, L.; Binder, R. J. J. Org. Chem. 2013, 78, 4762-4778; (c) Campbell, D. S.; Lawrie, C. W. Chem. Commun. 1971, 355-356; (d) Witzeman, J. S. Tetrahedron Lett. 1990, 31, 1401-1404.

(11) Hahn, K. N.; Fadeyi, O. O.; Cho, H. P.; Lindsley, C. W. Tetrahedron Lett. 2012, 53, 3577-3580.

(12) Holmquist, C. R.; Roskamp, E. J. J. Org. Chem. 1989, 54, $3258-3260$.

(13) Macrolactonization of 7 under typical Yamaguchi's conditions resulted in the formation of $\mathbf{6}$ in 33\% yield at $\mathrm{rt}$ and $15 \%$ yield under reflux.

(14) Bachrach, S. M. J. Org. Chem. 2008, 73, 2466-2468.

(15) Pettit, G. R.; Smith, T. H.; Feng, S.; Knight, J. C.; Tan, R.; Pettit, R. K.; Hinrichs, P. A. J. Nat. Prod. 2007, 70, 1073-1083.

(16) Kishimoto, S.; Nishimura, S.; Kakeya, H. Chem. Lett. 2015, 44, 1303-1305. 